\title{
Impact of After-Sales Service on Customers' Retention of Mobile Telecommunications in
}

Nigeria

\author{
Fasanmi Olumuyiwa Oladapo \\ Department of Business and Entrepreneurship, \\ College of Humanities, Management and Social Sciences, \\ Kwara State University, Malete, Nigeria
}

\begin{abstract}
The idea of after-sales services has been adopted globally to provide the consumers after the product or services rendered. The study explored the impact of after-sales services on customers' retention of mobile telecommunication in Nigeria. Survey research was adopted, and the aim of using this design is premised on the fact that the study relied on obtaining information from the field using a questionnaire. The population consist of all the subscribers of MTN, Globacom, Airtel and 9mobile. Four hundred seventy-two (472) subscribers of mobile networks were proportionally drawn from the NCC website. Subsequently, a simple random sampling technique was used to select the respondents from each of the mobile networks. The regression of [t-statistics] value of .01 and [2.63] demonstrates that the relationship between after-sale service and retention of customers is essential because the alpha level of 0.05 is higher than the p-value. Hence, the assumption is that growth in after-sales activities is a significant contributor to customer retention. Management should pay attention to the employee position to the quality of after-sales service, which results in future procurement and further recommendations.
\end{abstract}

Keywords: After-sales services, customer retention, brand loyalty, quality service, mobile telecommunications

Jel Classification : D11

\section{INTRODUCTION}

The concept of After-Sales Service (ASS) or After-Sales Support has been adopted widely by many service organisations, including the academics, professionals in the fields of social and management sciences to describe service that is provided to the consumers after the product or service has been rendered. It is an essential and a way to encourage the prospective buyer of the product and service in the first place. For instance, the 
provision of a warranty for the goods and services rendered, free service after six months, advise on how to use the product or service, a follow-up phone call etc.

The goods and services offered by the telecoms companies trigger more frequent customer switching behaviour, making it difficult to achieve the goal of the consumers' loyalty precisely to a specific brand image of the given organisation. There is much data among GSM subscribers in Nigeria regarding brand swapping practices (Aminu \& Hatini, 2018; Oyeniyi \& Abiodun, 2010). Business organisation globally strives to achieve brand loyalty and to achieve re-buy tendencies because of the presumed remunerations correlated with the idea. The issue of brand loyalty becomes the main focus of the organisation in today's competitive arcade (Ogbojafor, Ladipo, Patrick \& Odunewu, 2014). It is demonstrated by continuous patronage of the supplier's product or services, and the customer continues to spread a positive brand image about the satisfaction experienced when meeting the expectations of the customers (Ryu \& Moon, 2012).

Offering various channels along the customer journey of information search, purchase, and after-sales service to meet changing customer needs and preferences poses severe challenges for marketing managers. Firms are paying more and more attention to maintaining a loyal customer base in the increasingly competitive telecommunications market. Loyal clients often cost less to serve, spend more time with the business and provide a good source for new businesses. Dissatisfaction, on the other hand, weakens the consumer base and erodes the company's reputation. For service industries with a large and negative impact on profitability, consumer dissatisfaction is a severe problem (Aaker, 2016).

However, some of the organisations in the sector are unaware of the tool and its impact on customer retention. Failure to acknowledge the significance of after-sale service may lead to customers' dissatisfaction and ultimately resulted in a destructive and threatening relationship, despite the enormous efforts made by GSM service providers to accomplish the greater extent of customer patronage by fulfilling the subscribers profitably mainly via the services rendered after-sales. It seems as if the strategies and resources put in place were inadequate or better still inappropriately or inefficiently deployed.

Customer retention (or the degree of loyalty of the consumer to the company) will be greater the higher the level of consumer satisfaction. Telecommunications is probably one of Nigeria's fastest-growing sectors. The deregulation of the telecommunication 
sector by the Nigerian government in 2001 has led to an intensified competition amongst operators, i.e. MTN, Airtel, Glo \& 9Mobile. It is commonly believed that the restructuring of the market has significantly empowered consumers, who are no longer faced with a single operator decision taken; this has increased the existing rivalry. Moreover, the forces of liberalisation and globalisation of telecom market have pressurised the companies to look for a more robust strategy for survival in passing through a dynamic transitional phase, as it is undergoing the operation of market forces of demand and supply. In recent times, complaints of customers who are dissatisfied with service provider's services have been on the increase which has been primarily attributed to poor service quality delivery, unattended charges and so on; this has become subject of debate in public.

Acquisition and retention of new customers are parts of the most significant concerns for a service organisation; the mobile telecommunication industry is not exempted. The difficulties faced by GSM operators in the mobile telecommunication industry occasioned by the highly competitive rivalry among operators is evident as revealed by unabated brandswitching (Adegoke, Babalola \& Balogun, 2017). The intense competition in the telecom industry has made it extremely imperative for service providers to look beyond the traditional $4 \mathrm{ps}$ of marketing strategies and consider ASS as a complement to the subscribers and to achieve a competitive edge by the organisation. Meanwhile, customers feel secure when the supplier is available or involved in the installation and setting up of the goods or services bought. This means that after-sales service in the service sector context is one of the veritable tools for relating to customers. Its concern is about the usual activities of the mainly the members of their distribution channels.

The satisfaction of customers makes customers loyal to one provider of telecommunication services. Previous researchers have found that customer satisfaction can assist brands in establishing long and profitable customer relationships (Lele \& Karmarkar, 2013; Erevelles \& Leavitt, 2012; Gaiardelli, Saccani \& Songini, 2017). A company should therefore focus on improving aftersale service in order to satisfy its customers, which would ultimately help the company to retain its customers. It is costly, however, to generate satisfied and loyal clients, but that would prove profitable for a company in the long run (Anderson, 2008), while Ahmad and Buttle (2012) asserted that customer retention is not guaranteed with the provision of 
Fasanmi Olumuyiwa Oladapo

Impact of After-Sales Service on Customers' Retention of Mobile Telecommunications in Nigeria

support after-sales. Due to the inconsistency in the previous studies, this study tends to explore the impact of aftersales service on the customers' retention and loyalty of telecommunications.

\section{Research Question}

Given the above, the following research question will be answered in the course of this study:

"What is the impact of after-sales support on customer retention and loyalty of telecommunication".

\section{LITERATURE REVIEW}

\section{After-Sales Service}

Various scholars have explained the importance of after-sales service differently. This ASS was, for example, referred to as field services (Samuels, 2008). The other terms found in the literature describing the same are aftersales support (Agnihothri, Sivasubramaniam \& Simmons, 2012), technical support, and just services (Oliver \& Swan, 2009). Lele and Karmarkar (2013) used a few other terminologies, such as product support activities, and Loomba (2016) used customer support. Moreover, under the two perspectives in the literature, the term ASS was used. One viewpoint is linked to the companies that provide services. ASS is considered one of several additional services they provide (Oliver, 2013). The second view is related to companies that supply tangible products where after-sales service is linked to various operations (Gaiardelli et al., 2017). Transport and logistics, installation, product-related training and service repair may be such services.

Peck, Adrian, Christopher and Clark (2011) opined that service consumers are an increasingly significant source of competitive advantage. More and more companies have based their efforts in recent years on keeping existing clients, instead of gaining new ones. This was corroborated in Kotler (2012), hiring a new customer reflects five times the expense of holding current shareholders happy. Gaiardelli et al. (2017) describe ASS as those activities that take place after the product has been purchased, and that is dedicated to helping consumers use and dispose of the goods to make them loyal. According to Rigopoulou, Chaniotakis, Lymperopoulos and Siomkos (2018); Potluri and Hawariat (2010) the phrase after-sales services described from two different perspectives: when stating to service suppliers, after-sales services are seen as one of the complementary components of the service provided. At the other hand, when it comes to tangible goods, they are mostly seen as one or some of the relevant parties in the organisational activities of the supply chain. 
Loomba (2018), the critical aim of aftersales is to connect with the customers by the organisation's loyalty, reputation and sense of security, and create enduring relationships that lead to improved success for sustainable outcomes. Gaiardelli et al. (2017) said that an efficient after-sales service strategy is crucial for streamlining service management and fulfilling consumer needs, enabling you to enjoy customer satisfaction while still saving on the result and generating income. Henley headlight vision centre (Looy, Gemmel \& Dierdonck, 2017) shows more than 1,800 buyers who have purchased all of the care products offered in the United States. Not only does outstanding service improve ties with consumers who still feel committed to a company. This can also preempt ill will, which allows the company to get badmouth from disaffected consumers. According to Potluri and Hawariat (2010), after-sales service delivery is becoming increasingly important as companies do everything in their power to make a product or service more cost-effective, raise sales and profits, and satisfy the consumer demand.

Many corporate organisations, therefore, are unaware of the after-sales service issues and their influence on customer satisfaction. Failure to understand the value of the factors may lead to a challenging and catastrophic business relationship. It may result in customer dissatisfaction switching to a competitor or the company losing new customer potential related to adverse word-of-mouth effect. Every enterprise should, therefore, understand the intent and value of providing after-sales service and enforce it to please customers by making them satisfied.

Loomba (2016) shields more light on the after-sales goals of keeping customers satisfied through the organisation's confidence, credibility and sense of security, and retaining the right people that contribute to enhanced performance for improved outcomes. ASS can create sustainable relationships with customers and contribute significantly to customer satisfaction, as Kurata and Nam (2010) have pointed out. The supplier can ensure product functionality and thus the satisfaction of customers by providing different ASS during the different phases of the product life cycle, which can help build a fruitful relationship between the supplier and the customer over time, allowing for more transactions (Egan, 2011). The most profitable customers are returning (Hoffman and Bateson 2010; Jacob and Ulaga 2008) and the cost to attract a new customer is five times higher than that to keep existing customers happy (Kotler 2012). ASS has, therefore acquired a critical role as a means of improving the 
satisfaction and retention of customers (Hellier, Geursen, Carr \& Richard, 2013).

While the key points for ASS were made in Johnston and Kong (2015) I improving long term brand identity and loyalty to the service organisation. (ii) providing ASS helps to persuade customers to trust the company and first to buy the service. (iii) word-of - mouth suggestion is influenced by sales. (iv) help the organisation balance the customer's satisfaction, and the cost of maintenance are not burdened. For example, an organisation can offer a free service, so that a clearly defined price for additional service is available. (v) ASS shall extend guarantees on the purchased goods and services; (vi) ASS may be used as a chance to offer related goods.

\section{Customer Retention and Loyalty}

Retention represents a coordinated initiative to minimise or eliminate problems. The retention process is to fulfil their needs and to take specific actions to meet their needs. The preservation of consumers is the activity in which a selling organisation reduces customer defects. A company begins with a customer and maintains a partnership for good customer retention over its entire lifespan. A company can draw new customers and retain existing ones. It is not only linked to its goods or services but also to how it represents its future clients and generates a market-wide brand identity (Oliver, 2013).

Customer retention is much more than just giving the consumer what they anticipate; it's about moving beyond their expectations to become loyal customers for their company. Customer loyalty brings 'customer value' instead of maximising business strategy profits (Greenberg, 2001). Customer retention is a strategic mechanism that maintains or preserves current customers and does not encourage them to converge or migrate for business with other suppliers or organisations, and this is only feasible if a quality partnership exists among customer and supplier. Generally, a consumer is likely to stick to one product or service over another brand or company to the degree that its basic needs continue to be appropriately met. The more you hold your customers, the higher the opportunity for market growth (Elmayar, 2011).

Post-sales services play an important role in determining the retention of consumers and the resulting rate of repurchase. Considering that a client with issues relating to post-sales and services tends to switch to other competing products, it should be reasoned that the impact of post-sales services on consumer perception of quality products is strong (Oko and Onuoha, 2013). Post-sales services catalyse to enhance buyer recognition and devotion 
among satisfied customers and to transform them, thereby improving company productivity (Oyeniyi \& Joachim, 2018).

Customer loyalty indicates that clients are committed to buying a particular service provider's products and services and will avoid the actions of rivals trying to subvert their patronage. Egan (2011) encapsulates the term loyalty as the selective behavioural response articulated over time by consumers to one supplier out of several suppliers that is a feature of decisionmaking and assessment process resulting in brand or store engagement. Peppers and Rogers (2008), approach consumer engagement from two separate ways: behavioural and attitudinal. The concept of loyalty attitudinal means loyalty is a state of mind. If consumers have an optimistic, favourable attitude towards a brand or service, they are loyal to it. They like the firm, its products or its brands and prefer buying from it, rather than from the competitors of the company. It is believed that the majority of customers are faithful to their preferred service provider and have a fulfilling and lasting positive ongoing relationship. Loyalty must be seen as biased conduct of repeated transactions, or repeated patronage followed by a favourable attitude. Upon receiving a customer's order, many businesses tend to focus on searching for new customers. They do not know the significance of preserving and improving relationships with their existing customers, i.e. there is too little emphasis on repeat business generation.

\section{After-sales Service and Customer Retention}

The following studies have shown that the quality of the after-sales service has a positive impact on perceived value, behavioural intent and customer satisfaction (Choudhary, Akhter, Asif, Choudhry, Siddique and Mughal, 2011) and Rigopoulou et al. (2018) studies. Aftersales is an essential means of gaining customer loyalty (Nasir, Mushtaq \& Rizwan, 2014). A business can build, retain and enhance consumer loyalty by providing superb after-sales services, such as prompt response to customer complaints, replacement of the defective goods or full reimbursement of a product or service when customers are not satisfied (Nasir et al., 2014).

Maintenance and repair are also an integral part of after-sales support or service (Loomba, 2018). One approach to get fast consumer feedback is to offer loaner product, especially in the breakdown incident, where possible (Loomba, 2016). Maintenance problems should be resolved before any failure happens (Fites, 2015). The best solution for organisations, however, is to provide the repair goods 
facility (Lele \& Karmarkar, 2013). Another critical aspect of the post-sales operation or customer care is updating. That gives consumers a chance to boost the existing product's efficiency (Cespedes, 2015). Online/telephone assistance is nowadays also the main feature of after-sales operation in different businesses. The consumers are given telephone/online assistance or advice by-product or service experts (Armistead \& Clark, 2012). Therefore, if an issue is solved electronically, the expense is too low than a product or service specialist's (i.e., an engineer or lineman) visit to the buyer's location (Armistead \& Clark, 2012). Online/telephone support in softwarerelated items usually needs more (Armistead \& Clark, 2012). Many organisations, for example, have started investing valuable assets in phone/online centres (i.e., Microsoft) (Dubashi, 2012).

The primary goal of every company is to satisfy its current customers and attract new customers. In this respect, after-sales service activities contribute significantly to customer satisfaction; after selling the product or service, they are provided by the seller to the buyer (Murali, Pugazhendhi \& Muralidbaran, 2016). Generating superior customer service is the secret to establishing a long-term relationship and increasing customer loyalty. It aims to boost consumer satisfaction (Yuen \& Chan, 2010). Yet service on request, social interaction, problem-solving, and advertising approaches have a strong relationship to retention and loyalty (Yuen \& Chan, 2010). Maghsoudlou, Mehrani, and Azma (2014) found a clear link between after-sales services and satisfaction services. The quality of after-sales service (Nemati, Khan, \& Iftikhar 2010) is a primary factor in influencing the customer purchasing decision.

Oliver (2018) suggested a framework of disconfirmation of customer satisfaction which is widely used in marketing today. Upon receiving the product or service, it describes the difference between consumer expectation and experience. Consumer retention is thus considered one of the essential elements for improving the intent of customer repurchase and for building a lifelong marketing relationship with the consumer. (Bai, Law \& Wen, 2018; Erevelles \& Leavitt, 2012; Kim, Ma \& Kim, 2016; Morgan, Attaway and Griffin, 2016). After-sales support, however, also helps to create long-term relationships, reward customers and get loyalty (Yuen \& Chan, 2010). Good consumer-like brand loyalty can be harnessed by companies (Anderson 2008). Customer loyalty satisfaction is considered a precedent (Forgas, Moliner, Sánchez, \& Palau, 2010). 
Oliver (2013) described loyalty as highly ensuring a favourite product, brand or service to order, re-patronise, or continue to purchase in the future." Consumers considered to be the company's most valuable asset and play a significant role in the company's success (Shahrouzifard \& Faraji, 2016). When an organisation wants to optimise business performance, customer satisfaction and loyalty, it must concentrate on satisfying its customers. Satisfaction will help increase an organisation's revenue, customer satisfaction and loyalty (Posselt \& Gerstner, 2015). To sustain a steady level of profitability and sales while the competition is extreme, the subscription level is very close to the saturation point; and the market is mature, businesses will follow a defensive strategy rather than an offensive one to attract current customers, which will help to increase market share (Ahmad \& Buttle, 2012). First, organisations that battle loyalty will concentrate on awareness and overall interest (Yang \& Peterson, 2014).

\section{Empirical Review}

Wali and Nwokah (2018) attempted to understand Nigeria mobile telecommunications (MT) consumers' voice call and data services expectations for delivering satisfactory and competitive service experiences. Their study was conducted using multi-level qualitative research designs with a one-person interview (F2F), and focus group (FG) approaches. Twenty-two samples have been taken in the Port Harcourt-Rivers State of Nigeria, MT heterogonous consumer population sector. One FG with 12 participants and $10 \mathrm{~F} 2 \mathrm{~F}$ interviews were conducted, and data analysed using NVivo 11 software content analysis technique. The findings show that individual customers in selected companies are less satisfied. Because these companies do not know the expectations of their customers. Also, five positively rated factors: service quality, price bundling, complaints management, consumer right education and consumer market research are key thematic expectations that support the delivery of satisfactory services experience and competitiveness.

Garín-Muñoz, Pérez-Amaral, Gijón and López (2015)' study analysed the postpurchase behaviour of mobile phone users once they have experienced a service failure. Given existing Consumer Complaint Behavior (CCB) literature, a survey was used in Spain by 4249 individuals to determine econometric equations which explain both the determinants of the decision on the complaint and the overall impact of proper complaint management. Results show that dissatisfaction is not a necessary prerequisite for complaint, and 
that complaints tend to differ according to the customer's problems. Another conclusion is that the company can correctly handle complaints are a source of improved user satisfaction and profitability for the company.

Murali, Pugazhendhi and Muralidharan (2016) studied ASS's customer satisfaction effect, and the customer satisfaction influence of the ASS attributes selected. A SERVQUAL model was used in conjunction with several regression analyses. The customer views on its ASS operations were collected and analysed using the SPSSAMOS 21 as a business case involved with the production of domestic equipment. The study results found that the SERVQUAL based ASS attribute is well linked to the satisfaction of the customer and that the mediator's role in affecting ASS quality plays the reliability dimension.

The Wajeeha and Kashif (2020) study seek to identify the effect of the quality of delivery of post-sales service on retail customer satisfaction. Besides, the overall impact of satisfaction on word - of - mouth and intention to repurchase. A sample of 330 answers was obtained from the customers buying a piece of electronic equipment (AUPS or air conditioner) via questionnaire by deliberate sampling technique. To measure the relations between structures by the SPSS and Amos, EFA, CFA and SEM analyses were performed. The result shows that delivery of quality after-sales services affects customer satisfaction, which results in the intention to repurchase and word-ofmouth.

\section{Theoretical Framework}

The TPB was premised that humans appear to act consciously. Taken into account the knowledge available and consider the consequences of their behaviour indirectly or explicitly (Ajzen 2005). Ajzen \& Fishbein (1980) refers among other studies, to several individual meta-analyses performed to prove that the associations between intention and actions are typically significant. Hence, he presumes that when people influence behavioural performance, they appear to behave according to their expectations (Ajzen, 2005).

Intentions are a function of three fundamental determinants according to the TPB. One is personal, one reflects the social influence and social pressure, and the third is about control issues. The psychological dimension of the defendant is his attitude towards the acts. This attitude is the positive or negative appraisal of the person who conducts the particular exciting behaviour. The second determinant of intention is the subjective norm, consisting, or not, of the perception of the social pressure of the individual to 
conduct the action under consideration. Finally, the ultimate determinant of purpose is the sense of self-efficacy or desire to perform value behaviour, called perceived. The psychological dimension of the defendant is his attitude towards the acts. This attitude is the positive or negative appraisal of the person who conducts the particular exciting behaviour.
The second determinant of intention is the subjective norm, consisting, or not, of the perception of the social pressure of the individual to conduct the action under consideration. Finally, the ultimate determinant of purpose is the sense of selfefficacy or desire to perform value behaviour, called perceived behavioural control.

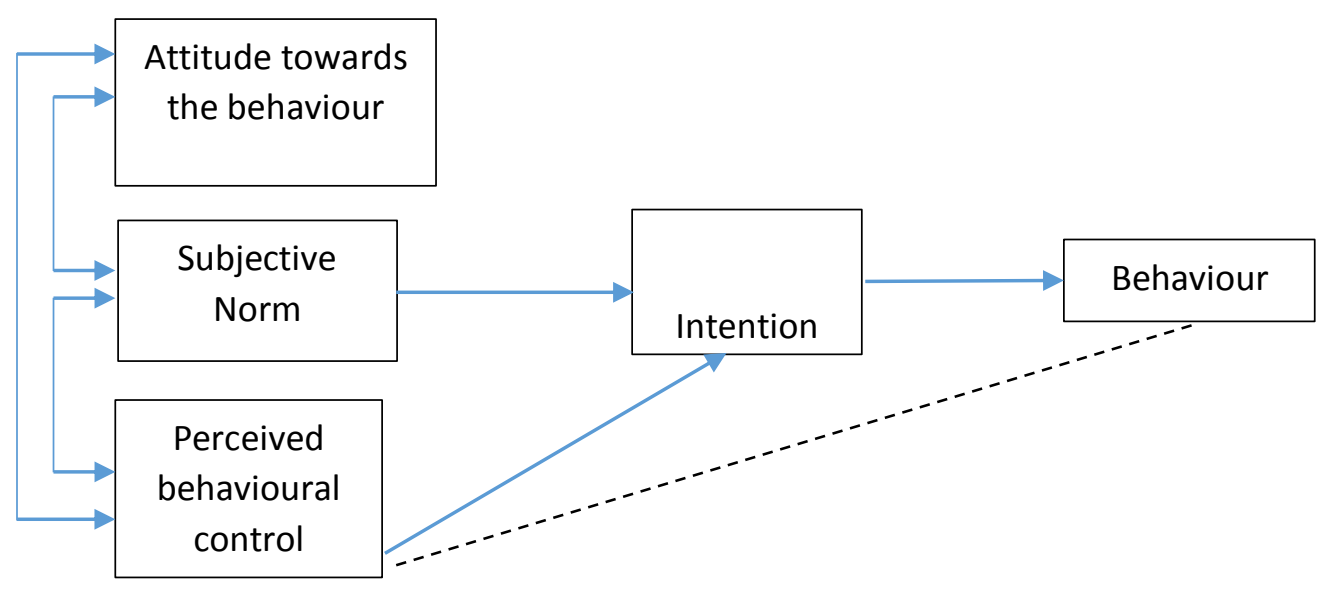

Figure 1: Intention Determinants

\section{Source: Adapted Icek Ajzen, University of Massachusetts (1992)}

To summarise the essence of the planned behaviour theory, people expect to perform a behaviour when evaluating it favourably, when feeling social pressure to do it, and when they feel they have the resources and incentives to do so (Ajzen, 2005). These three determinants are not always equally important, as attitudinal considerations are more vital for some intentions than normative considerations, while for others, it is vice versa. The importance of perceived behavioural influence often differs according to behaviour. In some cases, it takes only two determinants to explain the purpose, while in others, all three factors are significant. Even the relative weights of the three factors will differ from person to person, or from one population to another, according to Ajzen (2005). Hence, the TPB was explained from the contest of aftersales service and intention of customer to 
repurchase. This was done from the result, the following hypothesis was put perspectives of subjective norms, forward in nullity:

perceived behavioural control and attitudes towards the behaviour. The salient points in the TPB were reinforced by the application of this study, and as a

$\mathrm{H}_{01}$ : There is no significant impact of aftersales service on the repurchase intention of telecommunication subscribers.

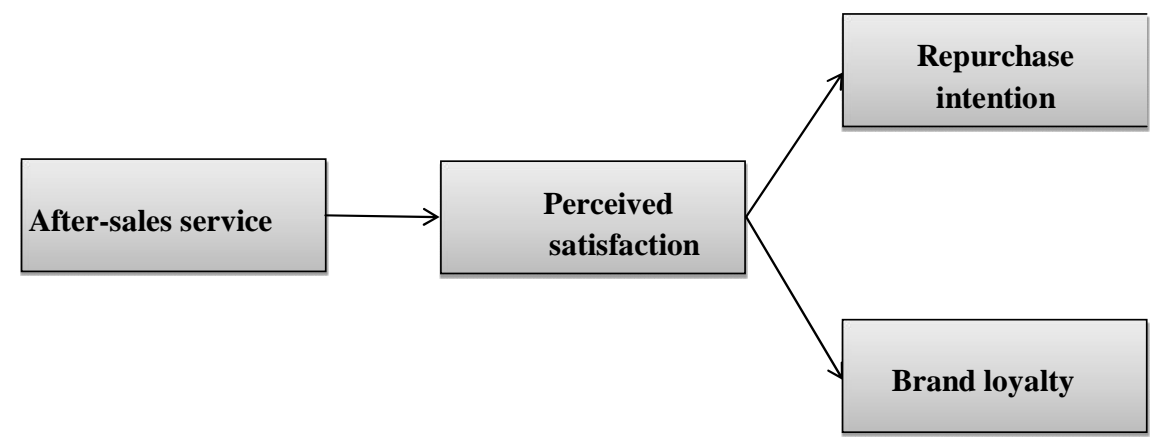

Figure 2: Conceptual Model, 2020

Source: Author's conceptualisation, 2020

\section{METHODOLOGY}

The design for this study is survey research, and the aim of using this design is premised on the fact that the study relied on obtaining information from the field using a questionnaire. The use of a questionnaire survey is most appropriate to sample the opinions of relevant stakeholders, i.e. the subscribers of the telecommunication industry. The population consist of all the subscribers of MTN, Globacom, Airtel and 9mobile. This is because they are keen competitors and has helped Nigerians to connect globally. It is impossible to gather information from the entire population of mobile telecommunication in Nigeria because of the time and cost involved. A sample obtained from the population can adequately represent the population. The sampling procedure used is simple random sampling, in which case every member of the population has an equal opportunity of being selected. Four hundred seventy-two subscribers of mobile networks were proportionally drawn from the NCC website. The technique considered the population of mobile networks in Nigerian each as a stratum. Subsequently, a simple random sampling technique was used to select respondent from each of the mobile networks, as shown in Table 1. 
Table 1 Strata of Mobile Telecommunication Networks

\begin{tabular}{lc}
\hline Mobile Network & Strata Sample Size \\
\hline MTN & 180 \\
Globacom & 140 \\
Airtel & 80 \\
9mobile & 72 \\
Total & 472 \\
\hline
\end{tabular}

Source: NCC Report, 2018

The correlation between the inputs of the performance scale and the correlation between component variable constructs shows convergent validity in that they are high and converge on a common base. The reliability and validity were examined further by calculating their alpha coefficient (Cronbach Alpha) after the survey had been completed. The Nunnally (1978) suggested that all scales exceed a minimum threshold of 0,7. Data collected were analysed using an application of simple percentage method in computer software packages (SPSS), and the regression analysis adopted by the testing of a reported hypothesis was considerable in testing the effect of two variables. SPSS, version 20.0 was used to analyse the data. In every case, the alpha value is set as 0.05 , which is to be tested at a level of 5 per cent.

\section{DATA PRESENTATION AND ANALYSIS}

Out of four hundred and seventy-two (472) copies of the questionnaire distributed, only three hundred and fifty-one (351) were returned, found usable and fit for the study, which is equivalent to $74.4 \%$ responses rate. The analysis of data was based on the $74 \%$ responses rate. 
Table 2: Socio-demographic Characteristics of Respondents

\begin{tabular}{|c|c|c|c|c|}
\hline \multirow{2}{*}{$\begin{array}{r}\text { Characteristics } \\
\text { Gender }\end{array}$} & \multirow{2}{*}{$\begin{array}{l}\text { Category } \\
\text { Male }\end{array}$} & \multirow{2}{*}{$\begin{array}{cc}\text { Frequency } & \text { Percent } \\
267 & \\
\end{array}$} & \multicolumn{2}{|c|}{$\begin{array}{l}\text { Cumulative } \\
\text { percent }\end{array}$} \\
\hline & & & 76.1 & 76.1 \\
\hline & Female & 84 & 23.9 & 100.0 \\
\hline \multirow[t]{4}{*}{ Age } & $20-35 y r s$ & 29 & 8.3 & 8.3 \\
\hline & $36-45 y r s$ & 107 & 30.5 & 38.7 \\
\hline & $46-55 y r s$ & 119 & 33.9 & 72.6 \\
\hline & 56yrs and Above & 96 & 27.4 & 100.0 \\
\hline \multirow[t]{4}{*}{ Marital Status } & Single & 104 & 29.6 & 29.6 \\
\hline & Married & 229 & 65.2 & 94.9 \\
\hline & Separated & 12 & 3.4 & 98.3 \\
\hline & Widowed & 6 & 1.7 & 100.0 \\
\hline \multirow[t]{3}{*}{ Highest Qualification } & NCE/OND & 8 & 2.3 & 2.3 \\
\hline & $\begin{array}{l}\text { HND/B.Sc. or } \\
\text { Equivalent }\end{array}$ & 125 & 35.6 & 37.9 \\
\hline & Postgraduate & 218 & 62.1 & 100.0 \\
\hline \multirow[t]{2}{*}{ Employment status } & Permanent & 330 & 94.0 & 94.0 \\
\hline & Contract & 21 & 6.0 & 100.0 \\
\hline
\end{tabular}

Source: Author's Computation, 2020

The frequency distribution of the demographic features of the respondents has illustrated in table 2 above. The table shows $267(76.1 \%)$ of the 351 respondents are male while 84 (23.9\%) are female. Although the findings recorded a higher number of male staff of the selected tertiary institutions than their female counterpart, by implication, it can be deduced that the views being expressed are representative of both male and female. Also, the table above captured the statistics on the age distribution of the respondents. From the table, majority of the respondents numbering 119 (33.9\%) are within 46-55 age bracket, 107 (30.5\%) within 36-45years, 96 (27.4\%) were within 56 years and above, and 29 (8.3\%) occupies 20 to 35 years. The finding is primarily dominated by staff between the age brackets of 46-55years. By implication, this deduced that the study has a more mature minded staff as respondents. 
More importantly, out of the 351 respondents, $229(65.2 \%)$ of the selected tertiary institutions are married, 104 (29.6\%) staff are single while 12 (3.4\%) staff are separated parents, and 6(1.7\%) are widowed. Hence, this means that the highest numbers of the employees are married. The figures as presented above narrates the educational background of the respondents where 218 respondents totalling to 62.1 per cent hold postgraduates certificates, 35.6 per cent which amounts to 125 respondents hold first degree certificates (i.e. HND/B.Sc. or Equivalent). In contrast, 8 employees who are 2.3 per cent of the respondents hold either OND or NCE certificates. This connotes that the highest numbers of employees sampled were educated above the first-degree educational level. By implication, means that the respondents were a resilient thoughtful of what the matter is all about. Lastly, 330 (94.0\%) of the sampled respondents are permanent employees of the selected tertiary institutions, while 21 (6.0\%) are contract staff. Hence, this by implication indicates that majority of the employees sampled are a permanent staff of the selected tertiary institutions.

\section{Test of Normality}

A standard curve for evaluating the normality of the dependent variables (i.e. repurchase intention and customer loyalty) may be drawn. Figure 3 provides a standard patronage scoring curve for the subscribers. Many of the parametric statistics presume that the scores are uniformly distributed on each of the variables (i.e., follow the usual curve shape). For this analysis, the ratings are distributed relatively normally, with most scores in the middle diminishing to the extremes:

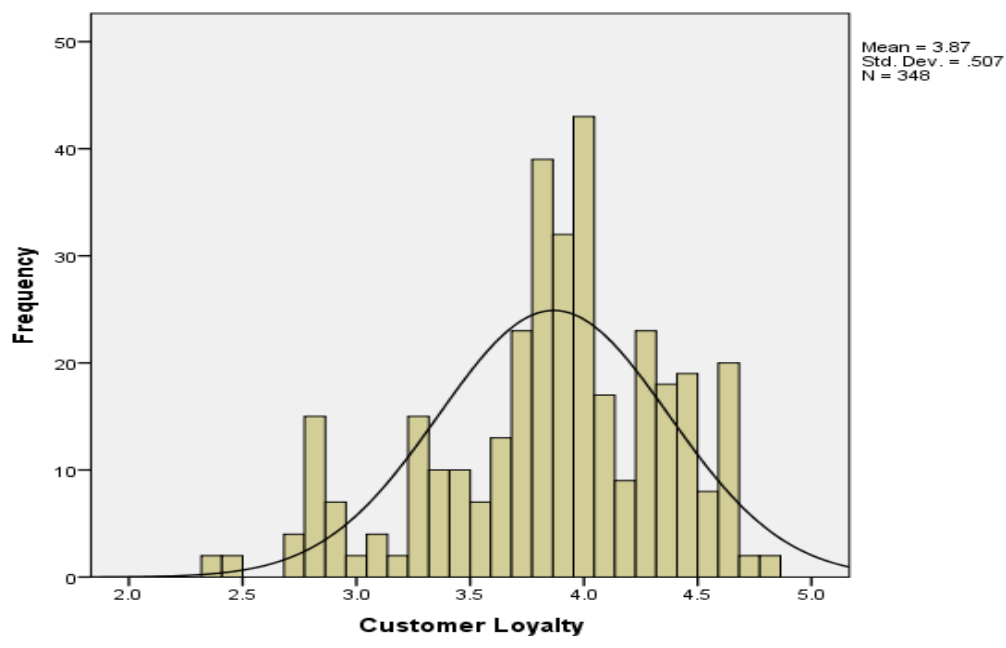

Fig 3: Histogram of Perceived Customers' Loyalty Scores 
Impact of After-Sales Service on Customers' Retention of Mobile Telecommunications in Nigeria

On the other hand, workers with low rates of perceived sales after service have far less perceived label preference. Eventually, respondents with high perceived levels of confidence report a high degree of perceived consumer loyalty and repurchase intention. At the other hand, workers with low perceived confidence rates have far less perceived loyalty to customers and repurchase intention. There is no sign of a curvilinear relationship (linearity test), and the scatter plots display a relatively even form of cigars along its length (homoscedasticity test).

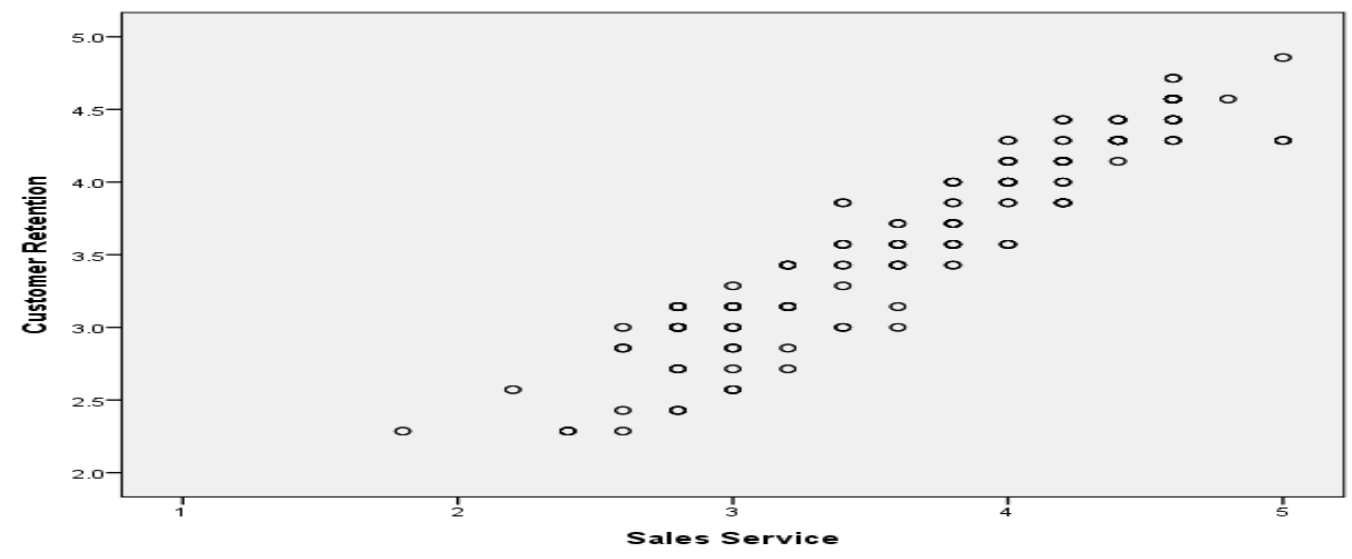

Figure 4: Histogram of perceived customer retention score

\section{Test of Hypothesis}

$\mathrm{HO}_{2}$ : There is no significant impact of after-sales service on the repurchase intention of telecommunication subscribers.

Multiple regression was used to investigate the impact of ASS (measured by the sales service scales) on perceived customer retention (measured by customer repurchase intention and loyalty). Table 3 describes the model. It shows that the correlation coefficient $r$ is 0.82 suggesting that there is a perfect relationship between the retention of customers (dependent variable, i.e. the variable being predicted) and the after-sale service (independent variables). It is also evident from the table that the $r 2$, which is the determination coefficient is around 68 per cent. This means that the availability of sales service may explain more than twothirds of the percentage, i.e. $68 \%$ improvement in customer retention. 
However, other variables that are not remaining 32 per cent. captured in the model clarify the

Table 3: Model Summary

\begin{tabular}{lcccrrr}
\hline Model & $\mathrm{R}$ & $\mathrm{R}$ Square & $\begin{array}{c}\text { Adjusted R } \\
\text { Square }\end{array}$ & \multicolumn{2}{c}{$\begin{array}{c}\text { Std. Error of } \\
\text { the Estimate }\end{array}$} & Durbin-Watson \\
\hline 1 & $.822^{\mathrm{a}}$ & .675 & .672 & .290 & 2.130
\end{tabular}

a. Predictors: (Constant), After-sales Service

b. Dependent Variable: Customer repurchase intention

Source: Author's Fieldwork Computation, 2020

Also, the outcome of regression indicates that the average F-test was 178.361, meaning $1 \%[p<.000]$ which is less than $0.05(p<0.05) p$-value. That implies that changes in the dependent variable (Customer Retention) will collectively influence the critical variable elements as a whole. Besides, Table 4.4.5b abridged the result of the variance in the dependent variable with square regression sum (60.19) as opposed to the residual amount of 28.94.

\begin{tabular}{|c|c|c|c|c|c|c|}
\hline \multicolumn{7}{|c|}{ Table 4: Coefficients ${ }^{\mathrm{a}}$} \\
\hline \multirow[t]{2}{*}{ Model } & & \multicolumn{2}{|c|}{$\begin{array}{l}\text { Unstandardised } \\
\text { Coefficients }\end{array}$} & \multirow{2}{*}{$\begin{array}{c}\text { Standardised } \\
\text { Coefficients } \\
\text { Beta }\end{array}$} & \multirow[t]{2}{*}{$\mathrm{t}$} & \multirow[t]{2}{*}{ Sig. } \\
\hline & & B & Std. Error & & & \\
\hline \multirow{3}{*}{1} & (Constant) & 1.166 & .104 & & 11.184 & .000 \\
\hline & After-sales & 101 & 030 & 111 & 2623 & 009 \\
\hline & Service & .104 & .059 & .141 & 2.033 & .009 \\
\hline
\end{tabular}

a. Dependent Variable: Customer repurchase intention

F-statistic: $178.361<0.000$

Source: Author's Computation, 2020

Specifically, the regression performance as shown in Table 4 that a positive relationship existed between perceived sales service and presumed customer retention, so that a unit increase in the level sales service scores resulted in approximately 0.104 unit increases in perceived customer retention scores, 
Fasanmi Olumuyiwa Oladapo

Impact of After-Sales Service on Customers' Retention of Mobile Telecommunications in Nigeria

which were statistically significant at $1 \%$ with the aid of the p-value $(0$. It shows that customer satisfaction rises by 10.4 per cent with any change in the indicator. This thus suggests that the better the aftersales operation, the higher the retention of customers.

Decision Rule: As depicted on the table above, it is, therefore, established that taking into account (Sales Service) constant at zero, customer retention will be 1.166 . The findings presented further shows that taking other independent variables (After-sales Service) at zero, a unit increase in the modification of aftersales service would lead to 0.104 (10.4\%) increases in customer retention. Yet, the Null Hypothesis $\left(\mathrm{H}_{\mathrm{O} 2}\right)$ is rejected on the basis that the $p$-value is 0.009 , which is far less than 0.05. Hence the alternative hypothesis is accepted, that there is a significant impact of after-sales service on the repurchase intention of telecommunication subscribers

\section{Discussion of Findings}

There is no important connection between after-sales operation and retention of customers. Regression analysis was introduced, and the result showed that the coefficient point of 0.10 indicates a moderate positive relationship exists between after-sale service and retention of customers. However, the likelihood and [tstatistics] value of .01 and [2.63] demonstrates that the relationship between after-sale service and retention of customers is essential because the alpha level of 0.05 is higher than the p-value. Hence, the assumption is that growth in after-sales activities is a significant contributor to customer retention. This is evident in studies (Loomba, 2018 and Gaiardelli, et al. 2017), which found that the main aim of after-sales is to retain customers through the confidence, reputation, and sense of security of the company, and create enduring relationships that lead to improved success for sustainable results. The study results also showed that an efficient after-sales service protocol is necessary for streamlining service management and meeting customer standards, enabling you to enjoy customer satisfaction while also saving on the bottom line, generating a profit and retaining customers.

\section{Conclusions and Recommendations}

In light of the results, the after-sales service shows that overall perceived service quality has an effect that thus affects behavioural requirements, i.e. intention to repurchase and brand loyalty. That is, the quality of sales service improves the consumer's relationship with the company and creates satisfaction. Improved quality of sales services gives the customer a sense of pleasure and reinforces the relationship between buyer 
and seller. The results demonstrate that the value-added experience of customers after-sales services is tactical. Sales service quality may be offered to customers for the satisfied customer to create a distinction in overall offerings. This ASS distinguishing can boost retailers' sales over the longer term. By delivering product quality, firms can maintain a strong bond with the customer and create it.

Therefore, once the customer has met the after-sales service of the goods or services received, it can be claimed that the consumer is organically encouraged to spread a positive word to the organisation. This assists the company in recommending the goods or services to friends and family and remains faithful to its customers. Overall satisfaction also enhances the customer's future buying behaviour from the same service provider. The study, therefore, recommends that managers pay attention to the employee position to the quality of after-sales service, which results in future procurement and further recommendations. Besides, every enterprise should understand the intent and value of providing after-sales service and enforce it to please customers by making them satisfied.

\section{References}

Aaker, D.A. (2016). Measuring brand equity across products and markets,
California Management Review, 38(3), 102-120.

AbdulAziz, A. R., Saeed, B.I. \& Alexander, A. (2014). Customer satisfaction of mobile telecommunication networks in Ghana: service delivery perspective. Journal of Accounting Management, 14(1), 61-71

Adegoke, A. S., Babolola, I. T. \& Balogun, W. A. (2017). Performance evaluation of GSM mobile system in Nigeria, The Pacific Journal of Science and Technology, 9(2), 436-441.

Agnihothri, S., Sivasubramaniam, N. \& Simmons, D. (2012). Leveraging technology to improve field service, International Journal of Service Industry Management, 13(1), 47-68.

Ahmad, R. \& Buttle, F. (2012). Customer retention management: A reflection of theory and practice, Marketing Intelligence \& Planning, 20(3), 149161.

Ajzen I. \& Fishbein M. (1980). Understanding Attitudes and Predicting Social Behaviour. London: Prentice-Hall.

Ajzen Icek (1991). The theory of planned behaviour, Organizational Behaviour and Human Decision Processes, 50, 179-211.

Ajzen Icek (2005). Attitudes, Personality and Behaviour (2 $\left.{ }^{\text {nd }} E d.\right)$. New York: Open University Press. 
Albanese, J.S. (2017). The nature of preferences: An exploration of the relationship between economics and psychology, Journal of Economic Psychology, 8(1), 3-18.

Aminu, A. \& Hartini, A. (2018). Marketing mix drivers of clients' satisfaction in technology enabled service: Study of Nigerian GSM subscribers, Communications of the IBIM, 1, 8490.

Anderson, E. W. (2008). Customer satisfaction and word of mouth, Journal of Service Research, 1(1), 517.

Anselmsson, J., Johansson, U. \& Persson, N. (2018). The battle of brands in the Swedish market for consumerpackaged food: A cross-category examination of brand preference and liking, Journal of Brand Management, 16(1), 63-79.

Armistead, C. G. \& Clark, G. (2012). Customer service and support: Implementing effective strategies. London: Financial Times-Pitman.

Armitage C. \& Conner M. (2001). Efficacy of the theory of planned behaviour: A meta-analytic review, British Journal of Social Psychology 40(4), 71-99.

Bai, B., Law, R., \& Wen, I. (2018). The impact of website quality on customer satisfaction and purchase intentions: Evidence from Chinese online visitors, International Journal of Hospitality Management, 27(3), 391-402.

Cespedes, F. V. (2015). Concurrent Marketing: Integrating product, sales, and service. USA: Harvard Business Press.

Choudhary, A. I., Akhter, S. A., Asif, M., Choudhry, R. M., Siddique, Z., \& Mughal, A. (2011). Impact of aftersale service characteristics on customer satisfaction, Information Management and Business Review, $3(6), 360-365$.

De Chernatony, L. \& Riley, F.D.O. (2008). Defining a brand: beyond the literature with experts' interpretations, Journal of Marketing Management, 14(5), 417-443

D'Souza, G. \& Rao, R. C. (2015). Can repeating an advertisement more frequently than the competition affect brand preference in a mature market, Journal of Marketing, 59(2), 32-42.

Dubashi, J. (2012). Customer Service: Word Perfect, Financial World, 161(19), 58. Egan, J. (2011). Relationship management - Exploring relational strategies in marketing. London: Prentice-Hall.

Elmayar, A. (2011). Assessing the perceived service quality levels in the Libyan private and public banking 
sectors: A customer perspective. London: McGraw Hill.

Erevelles, S. \& Leavitt, C. (2012). A comparison of current models of consumer satisfaction/dissatisfaction, Journal of Consumer Satisfaction, Dissatisfaction and Complaining Behaviour, 5(10), 104-114.

Fites, D. V. (2015). Make your dealers your partners, Harvard Business Review, $74(2), 84$.

Forgas, S., Moliner, M. A., Sánchez, J. \& Palau, R. (2010). Antecedents of airline passenger loyalty: Low-cost versus traditional airlines, Journal of Air Transport Management, 16(4), 229-233.

Gaiardelli, P., Saccani, N. \& Songini, L., (2017). Performance measurement systems in after-sales service: an integrated framework, International Journal of Business Performance Management, 9 (2), 145-171.

Garín-Muñoz, T., Pérez-Amaral, T., Gijón, C. \& López, R. (2015). Consumer complaint behaviour in telecommunications: The case of mobile phone users in Spain. Telecommunications Policy (2015), http://dx.doi.org/10.1016/j.telpol.2 $\underline{015.05 .002 i}$

Greenberg, P. (2001). CRM at the speed of light, capturing and keeping in internet Real-Time Berkeley, Osborne: McGraw-Hill.

Hellier, P. K., Geursen, G. M., Carr, R. A. \& Rickard, J. A. (2013). Customer repurchase intention: A general structural equation model, European Journal of Marketing, 37(11/12), 1763.

Hsee, C.K., Yang, Y., Gu, Y. \& Chen, J. (2009). Specification seeking: How product specifications influence consumer preference, Journal of Consumer Research, 35, 952-966.

Johnston, R. and Kong, M. (2015). A framework for developing a quality strategy in a customer processing operation, International Journal of Quality \& Reliability Management, 4(4), 37-46.

Kim, W. G., Ma, X. \& Kim, D. J. (2016). Determinants of Chinese hotel customers' e-satisfaction and purchase intentions, Tourism Management, 27(5), 890-900.

Kotler, P., 2012. Marketing Management (Millennium ed.), Custom Edition for the University of Phoenix. (10th ed). USA: Pearson Custom Publishing.

Lele, M. M. \& Karmarkar, U. S. (2013). Good product support is smart marketing, Harvard Business Review, 61(6), 124-132.

Loomba, A. (2018). Product Distribution and Service Support Challenge 
Linkages: an empirical validation, International Journal of Physical Distribution \& Logistics Management, 28(2), 143- 161.

Loomba, A. P. (2016). Linkages between product distribution and service support functions. International Journal of Physical Distribution \& Logistics Management, 26(4), 4-22.

Looy, B.V., Gemmel, P. \& Dierdonck, R.V. (2017). Services Management: an integrated approach (2nd ed.). Essex: Prentice-Hall.

Maghsoudlou, Z., Mehrani, H. \& Azma, F. (2014). The role of after-sales service in customer satisfaction: A case study (Samsung house appliances), International Research Journal of Management Sciences, 2(6), 175-179. Mansori, S., Tyng, G.G. \& Ismail, Z. M. (2014). Service Recovery, Satisfaction and Customers' Post Service Behavior in the Malaysian Banking Sector. Management Dynamics in the Knowledge Economy, Volume 2 (2014) no. 1 , pp. $5-20$

March, J. M. (2008). Bounded rationality, ambiguity, and the engineering of choice, Journal of Economics, 9(2), 587-608.

Morgan, M. J., Attaway, J. S. \& Griffin, M. (2016). The role of product/service experience in the satisfaction formation process: $A$ test of moderation, Journal of Consumer Satisfaction Dissatisfaction and Complaining Behaviour, 9, 104-114.

Murali, S., Pugazhendhi, S. \& Muralidharan, C. (2016). Modelling and investigating the relationship of after-sales service quality with customer satisfaction, retention and loyalty-a case study of home appliances business, Journal of Retailing and Consumer Services, 30, 67-83.

Nasir, A., Mushtaq, H. \& Rizwan, M. (2014). Customer loyalty in telecom sector of Pakistan, Journal of Sociological Research, 5(1), 449-467.

Nemati, A. R., Khan, K. \& Iftikhar, M. (2010). Impact of innovation on customer satisfaction and brand loyalty, a study of mobile phones users in Pakistan, European Journal of Social Sciences, 16(2), 299-306.

Ogbojafor, B. E. A., Ladipo, K. A. Patrick I. O. S. \& Odunewu, A. V. (2014). Determinants of customer satisfaction and loyalty in the Nigerian telecommunications industry, British Journal of Marketing Studies, 2(5), 67-83.

Oliver, R. L. \& Swan, J. E. (2009). Consumer Perceptions of Interpersonal Equity and Satisfaction in Transactions: A Field Survey Approach, Journal of Marketing, 53 (4), 21-35. 
Oliver, R. L. (2013). Whence consumer loyalty? The Journal of Marketing, 33-44.

Oliver, R. L. (2018). A conceptual model of service quality and service satisfaction. Boston, MA: McGrawHill.

Oyeniyi, J. O. \& Abiodun, J. A. (2010). Switching cost and customer loyalty in the mobile phone market: The Nigerian experience, Business Intelligence Journal, 3(1), 111-121.

Oyeniyi, O. \& Joachim, A. A. (2018).

Customer Service in the Retention of Mobile Phone Users in Nigeria, African Journal of Business Management, 2 (2), 026-031.

Peck, H., Adrian, P., Christopher, M. \& Clark, M. (2011) Relationship Marketing: strategy and implementation. Oxford, Butterworth: Heinemann.

Peppers, D. \& Rogers, M. (2008). Rules to break and laws to follow, Ney Jersey: Wiley Hoboken.

Posselt, T. \& Gerstner, E. (2015). Presale vs. Post-sale satisfaction: Impact on repurchase intention and overall satisfaction, Journal of Interactive Marketing, 19(4), 35-47.

Potluri, R. \& Hawariat, H. (2010). Assessment of after-sales service behaviours of Ethiopia telecom customers, African Journal of
Economic and Management Studies, $1(1), 75-90$.

Rigopoulou, I. D., Chaniotakis, I. E., Lymperopoulos, C. \& Siomkos, G. I. (2018). After-sales service quality as an antecedent of customer satisfaction: The case of electronic appliances. Managing Service Quality: An International Journal, 18(5), 512527.

Ryu, S. \& Moon, C. W. (2012). Long-Term orientation as a determinant of relationship quality between channel members, The International Business \& Economics Research Journal, 8(11), 1-9.

Samuels, W. J. (2008). Information systems, preferences, and the economy in the JEl, Journal of Economic Issues, 12(1), 23-41.

Shahrouzifard, S. \& Faraji, M. (2016). After-sales service quality as an antecedent of customer satisfaction. Accounting, 2(2), 81-84.

Wajeeha, A. \& Kashif, F. (2020). Impact of after-sales service on consumer behavioural intentions. Int. J. Business and Systems Research, 14(1), 44-56.

Wali, A.F. and Nwokah, N.G. (2018) 'Understanding customers' expectations for delivering satisfactory and competitive services experience', Int. J. Electronic 
Fasanmi Olumuyiwa Oladapo

Impact of After-Sales Service on Customers' Retention of Mobile Telecommunications in Nigeria

Marketing and Retailing, 9(3), 254-

268.

Yang, Z. \& Peterson, R. T. (2014).

Customer perceived value, satisfaction, and loyalty: The role of switching costs, Psychology \& Marketing, 21(10), 799-822.

Yuen, E. F. \& Chan, S. S. (2010). The effect of retail service quality and product quality on customer loyalty, Journal of Database Marketing \& Customer Strategy Management, 17(3-4), 222-240. 